
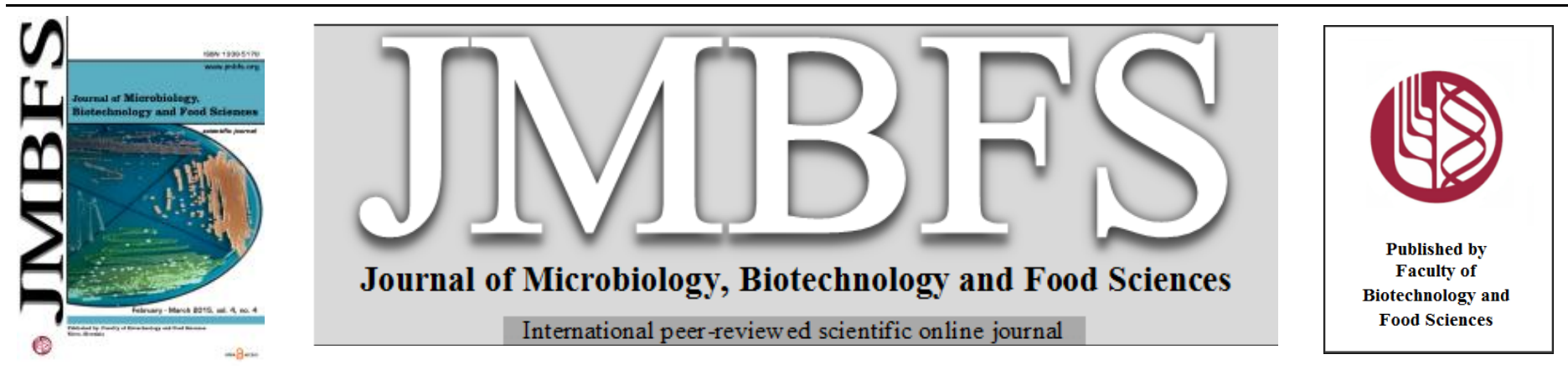

\title{
USE OF ZEIN AND ETHYLCELLULOSE AS BIODEGRADABLE FILM ON EVALUATION OF POST-HARVEST CHANGES IN TOMATO (Lycopersicum esculentum)
}

\author{
C.E. Chávez-Murillo ${ }^{1}$, V. Espinosa-Solis ${ }^{2}$, A. Aparicio-Saguilán ${ }^{3}$, R. Salgado-Delgado ${ }^{4}, J_{\text {M.M. Tirado-Gallegos }}^{5}$, P.B. Zamudio- \\ Flores ${ }^{5}$ *
}

\begin{abstract}
Address(es): Dr. P. B. Zamudio-Flores,
${ }^{1}$ Instituto Politécnico Nacional, Unidad Profesional Interdisciplinaria de Ingeniería Campus Zacatecas, Blvd. del Bote S/N, Col. Ciudad Administrativa, C.P. 98160 , Zacatecas, Zacatecas, México.

${ }^{2}$ Universidad Autónoma de San Luis Potosí. Coordinación Académica Región Huasteca Sur de la UASLP. Km. 5, carretera Tamazunchale-San Martin, 79960, Tamazunchale, S.L.P. México.

${ }^{3}$ Universidad del Papaloapan, Instituto de Química Aplicada. Circuito Central 200, Colonia Parque Industrial, C.P. 68301, Tuxtepec, Oaxaca, México.

${ }^{4}$ Instituto Tecnológico de Zacatepec, Departamento de Posgrado en Ingeniería Química y Bioquímica, Calzada Tecnológico 27, Zacatepec, Morelos, México.

${ }^{5}$ Centro de Investigación en Alimentación y Desarrollo, A.C.-Unidad Cuauhtémoc, Fisiología y Tecnología de alimentos de la Zona Templada. Avenida Río Conchos s/n, Parque Industrial, C.P. 31570, Ciudad Cuauhtémoc, Chihuahua, México.
\end{abstract}

*Corresponding author: pzamudio@ ciad.mx

doi: 10.15414/jmbfs.2015.4.4.365-368

\section{ARTICLE INFO}

Received 5. 12. 2014

Revised 14. 12. 2014

Accepted 7. 1.2015

Published 1. 2. 2015

Regular article

open $\partial_{\text {ACCESS }}$

\section{ABSTRACT}

The worldwide pollution index registered in the last decades has conducted to develop methods for biodegradation and reutilization of contaminant materials. From here rises the necessity to elaborate biodegradable packaging materials. In this study, a biodegradable zein and ethylcellulose based film was developed and used as a covering material to evaluate its effect on the enzymatic activity of pectinmethylesterase and polygalacturonase, texture, respiration rate and weight loss of tomatoes (Lycopersicum esculentum). Biodegradable film decreased the weight loss rate and softening of the fruits. However, enzymatic activity and respiration rate were not affected by the film application. The results showed that the changes in tomato are due to physical effects of water loss more than a metabolic change. By using this material, it was possible to lower tomato's respiration rate in comparison with controls causing a lesser loss of weight. Biodegradable film delayed change in color as well as texture compared with controls. There was a significant difference in pectin methyl esterase activity in the covered tomato, but there was no difference in polygalacturonase activity.

Keywords: Tomato, preservation, biodegradable film, modified atmosphere

\section{INTRODUCTION}

Metabolic activity of fruits and vegetables continues after harvested and stored in room conditions, suffering dehydration by transpiration, besides of being affected by the microorganisms present in the environment (Kader, 1986). In food preservation the use of modified atmosphere packaging is an important technique to extend post-harvest life of fruits and vegetables besides of improving quality (Exama et al., 1993). In modified atmosphere packaging, the natural process of respiration is used to reduce oxygen and increase carbon dioxide in conjunction with an appropriate gas exchange through the package. This gentile atmosphere modification decreases fruit respiration rate giving as a result a slower metabolism, retarding ripening and senescence (Cameron $\boldsymbol{e t}$ al., 1989). Tomato (Lycopersicum esculentum) is a seasonal vegetable rich in vitamins and minerals. Tomatoes deteriorate postharvest problem for traders, so edible films may have the potential to inhibit the rapid quality degradation (Das et al., 2013). Principa variables in the ripening of tomato are enzymatic activity, texture and color. The main problem in post-harvest of fruits and vegetables during storage is the excessive softening. Ripening of climacteric fruits like tomato is due to biosynthesis of ethylene that breaks out biochemical and physiological processes leading to softening. According to some researchers, polygalacturonase (PG) and pectin-methyl-esterase (PME) are the most important hydrolases involved in the softening process (Barka et al., 2000). PME is widely distributed in higher plants and catalyzes the demethylation of pectin. Partially deesterified pectin can be easily depolymerized by PG, an enzyme that is found in large quantities in tomatoes (Van den Broeck et al., 2000). Materials used for package elaboration in modified atmosphere must have selective permeability and diffusion to gases. The packaging material has to be semi-permeable to give as a result a modified atmosphere in equilibrium. An ideal film should allow a greater exit of carbon dioxide than inlet of oxygen (Zagory and Kader, 1988). Besides of being a gas barrier, packaging can help in the maintenance of a high environmental relative humidity inside of it, to preserve turgency of fruits and vegetables. However, maintaining a very high relative humidity can also promote condensation of humidity in the product, creating favorable conditions for the growth of spoilage and pathogenic bacteria. There has been an extensive research work to develop alternative materials that include proteins, polysaccharides and fatty acids, alone or in combination to be used for packaging in modified atmospheres of fruits and vegetables. Those packaging materials can be easily degraded at environmental conditions once their protective function has finished. Protein and polysaccharide films are excellent barriers against oxygen and carbon dioxide due to its tightly packaged network structure, ordered hydrogen bonds and poor solubility. Lipids offer a limited oxygen barrier due to the presence of microscopic pores, but they have good water vapor barrier properties (McHugh and Krochta, 1994). Carbon dioxide permeability of composite films containing a polysaccharide allow a delay in ripening of some climacteric fruits therefore increasing shelf life without creating severe anaerobic conditions (Zagory, 1995). Chitosan films have been used in apples and pears to reduce respiration rate in $50 \%$ (Baldwin, 2005) or in strawberries to reduce decay incidence (El Ghaouth et al., 1991). Films based on cellulose derivatives and fatty acid esters have been used in mangoes (DíazSobac et al., 1996) and guavas (McGuire and Hallman, 1995). Also, emulsions of different fatty acids have been used to extend shelf life of peaches (Erbil and Muftugil, 1986) and mangoes (Castrillo and Bermudez, 1992). The objective of this work was to develop a zein and ethylcellulose based film and evaluate its effect on post-harvest changes of tomatoes during the ripening process.

\section{MATERIAL AND METHODS}

\section{Harvest and conditioning of raw material}

Mature-green tomatoes were harvested on March and October from different plantations in the southeast part of Chihuahua (Delicias, Chihuahua, Mexico). 
Fruits were washed and treated with a solution of sodium hypochlorite (10\%) before beginning the experiments. Fruits of uniform size, similar appearance and free from external defects were selected and then randomized for each treatment.

\section{Film preparation}

A mixture $(2.5 \mathrm{~g}, 50 / 50 \mathrm{w} / \mathrm{w})$ of ethylcellulose and zein (Sigma Chemical Co., St Louis, MO) were dissolved in $50 \mathrm{~mL}$ of ethanol (J. T. Baker Inc., Phillipsburg, $\mathrm{NJ}$ ) and kept at $75^{\circ} \mathrm{C}$ for $20 \mathrm{~min}$ while stirring. The mixture was cast on glass plates $(20 \times 20 \mathrm{~cm})$ using a thin layer chromatography spreader (Kamper and Fennema, 1985). Spreading thickness was fixed to $0.75 \mathrm{~mm}$ and coated plates were dried in a $75^{\circ} \mathrm{C}$ oven for 15 min. After drying and cooling, films were removed from plates, placed in plastic bags and stored at room temperature $(25 \pm$ $3{ }^{\circ} \mathrm{C}$ ) in desiccators over silica gel.

\section{Weight loss}

Three batches of eight tomatoes were used to measure weight loss during storage at $60 \% \mathrm{RH}$ and $20{ }^{\circ} \mathrm{C}$. The weight $(0.001 \mathrm{~g}$ precision $)$ was registered every two days during 14 days.

\section{Color}

Five tomatoes from each group were monitored for their surface color change using a Milton Roy (Model Color Mate, Osaka, Japan) colorimeter. Instrumental color readings $\left(L^{*}, a^{*}, b^{*}\right)$ were taken from five points on the surface of the tomatoes every two days. Hue angle $\left(\arctan b^{*} / a^{*}\right)$ and chroma, a parameter similar to color saturation or intensity $\left[\left(a^{2}+b^{2}\right)^{1 / 2}\right]$ were calculated (McGuire, 1992).

\section{Firmness}

The firmness was measured using a mechanically driven penetrometer (Model DF 15-100, Chatillon Co. Ltd., New York) equipped with a probe tip (masticability). Distance $(\mathrm{cm})$ and force $(\mathrm{kg})$ necessary to penetrate the tomato was registered.

\section{Enzymatic extracts}

Tomatoes were homogenized for one min in a $1.2 \mathrm{M} \mathrm{NaCl}$ solution with a proportion 2:1 using a food processor (Moulinex, Model AAT3R4). The homogenate was centrifuged at $4000 \mathrm{rpm}$ for $10 \mathrm{~min}$ and the enzymatic activity was determined in pectin methyl esterase (PME) extracts (Hagerman and Austin, 1986). Activity was reported as $\mathrm{mg}$ of galacturonic acid/min $\mathrm{mL}$ of extract. Activity of polygalacturonase (PG) was also determined using polygalacturonic acid as substrate (Mo. P-3889, Sigma Chemical Co., St. Louis, USA) at concentration of $0.5 \%(\mathrm{w} / \mathrm{v})$ in $\mathrm{NaCl} 0.2 \mathrm{M}, \mathrm{pH} 4.5$. Reaction mixture was incubated for $30 \mathrm{~min}$ at $37 \pm 1{ }^{\circ} \mathrm{C}$. Concentration of total reducing sugars was determined by a change in the color at $590 \mathrm{~nm}$ after adding 3-5 dinitrosalycilic acid.

\section{Respiration rate}

The respiration rate was measured in detached fruit by enclosing fruit in $1 \mathrm{~L}$ glass jars. $\mathrm{CO}_{2}$ levels were measured using a colorimetric method described by Prat and Mendoza Jr (1979). In this method, $3.5 \mathrm{~mL}$ of bromothymol blue solution is used with an air flow rate of up to $20 \mathrm{~L} / \mathrm{h}$. A colorimetric reaction takes place between the carbon dioxide of the fruit and the dye solution and tubes are read at $615 \mathrm{~nm}$.

\section{Statistical analysis}

Researchers used a completely random design. An analysis of variance (ANOVA) was used at a $5 \%$ significance level $(\alpha=0.05)$. Results were obtained and normality test was verified using a Sigma-Plot statistical program, version 11.0 (Fox et al., 1995). When significant differences were found, researchers applied the Tukey range test for the comparison of means (Walpole $\boldsymbol{e t}$ al., 1999).

\section{RESULTS AND DISCUSSION}

\section{Weight loss}

Package materials offer a barrier to water vapor, avoiding exit of fruit's humidity due transpiration. Fruits and vegetables loss water when relative humidity in the package is less than $80-95 \%$ and quality reduction occur if $6 \%$ of the humidity of the product is lost (Phillips, 1996). Figure 1 shows loss of weight (\%) during ripening of tomatoes with and without film. Control tomato loss its quality in 7 days of storage (temperature $20{ }^{\circ} \mathrm{C}$ and $\mathrm{RH}=60 \%$ ). However, film maintained tomato in optimal quality until $15^{\text {th }}$ day. Statistical analysis of data indicate that there is a significant difference in loss of weight of control tomato in comparison with the one covered with the film $(\mathrm{p}<0.05)$. When storage time was longer $(18$ days), control tomato had a loss of weight of $10 \%$. It had a dehydrated appearance and fungus grew at the surface. Meanwhile, the covered samples kept a good quality and a turgent appearance. Using the developed film allowed to keep the tomato quality during 15 day of storage.

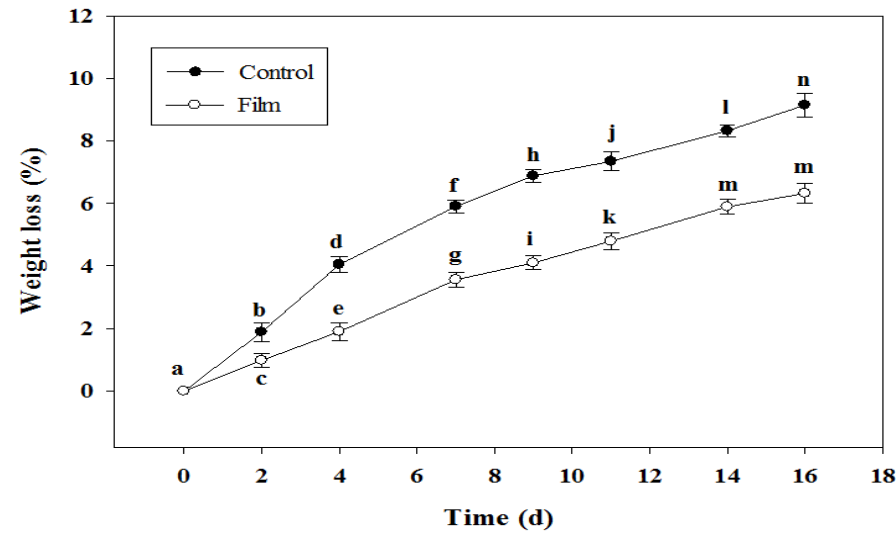

Figure 1 Weight loss of tomato with film and control tomato. Different letters show significant difference $(P<0.05)$.

\section{Color}

Changes in pigmentation during ripening of tomatoes are characterized by loss of chlorophyll and a rapid accumulation of carotenoids, particularly lycopene. In addition chloroplasts are converted to chromoplasts (Shewfelt et al., 1988). Table 1 shows the values of color determined by the CieLab system for covered tomatoes with film and controls during 20 days of storage. The statistical analysis of data indicates that there was significant difference between $L^{*}$ values $(P=$ $0.011)$ and Hue angle $(P=0.030)$ for covered tomatoes and control but there was no difference for chroma $(P=0.250)$. During ripening of tomato, $\mathrm{L}^{*}$ value decreased meaning that color ranged from a bright to an opaque color in the senescence (Artés and Escriche, 1994). In this study L* values ranged from 56.64 to 47.09 for tomatoes covered with the film. The development of the surface colour (hue angle) was delayed by the film from 100.65 to 42.14 . These results agreed with those of Artés et al. (1998) who studied the effect for intermittent warming on the ripening of tomatoes. Also, a similar trend was observed by Park et al. (1994) for tomatoes covered by an edible coating. During ripening, the color of tomatoes generally developed from " $\mathrm{a} / \mathrm{b}$ " ratios of -0.6 (mature green) to 2.2 (overripe) and commercially they are considered acceptable when $>0.8$ (yellow-orange). In this study, tomatoes covered with the film had an $\mathrm{a} / \mathrm{b}$ ratio of 1.02 after 21 days of storage. Color change $(\square \mathrm{E})$ was reached at the $5^{\text {th }}$ day of storage by control tomatoes, however in those covered with films, color change was reached until day 15 (Table 1). Loss of quality is attained at day 20 due to excessive loss of water.

Table 1 Color values of system CieLab for tomatoes covered by the film and controls. Different lowercase in the same column show significant difference $(P<0.05)$ on time evaluation and different capital letter in the same row show significant difference $(P<0.05)$ in same time evaluation.

\begin{tabular}{|c|c|c|c|c|c|c|c|c|c|c|}
\hline \multirow{3}{*}{$\begin{array}{l}\text { Time } \\
\text { evaluation } \\
\text { (days) }\end{array}$} & \multicolumn{10}{|c|}{ Color values } \\
\hline & \multicolumn{2}{|c|}{$\mathrm{L}$} & \multicolumn{2}{|c|}{$a^{*}$} & \multicolumn{2}{|c|}{$\mathrm{b}^{*}$} & \multicolumn{2}{|c|}{ Chroma } & \multicolumn{2}{|c|}{${ }^{\circ}$ hue } \\
\hline & Control & Film & Control & Film & Control & Film & Control & Film & Control & Film \\
\hline$\overline{\overline{0}}$ & $\overline{54.75^{\mathrm{aA}}}$ & $56.74^{\mathrm{aB}}$ & $-4.74^{\mathrm{aA}}$ & $-7.32^{\mathrm{ab}}$ & $37.29^{\mathrm{aA}}$ & 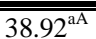 & $37.59^{\mathrm{cA}}$ & $39.60^{\mathrm{ab}}$ & $997.24^{\mathrm{aA}}$ & $\overline{100.65^{\mathrm{ab}}}$ \\
\hline 2 & $52.60^{\mathrm{bA}}$ & $54.91^{\mathrm{bB}}$ & $2.52^{\mathrm{bA}}$ & $-5.48^{\mathrm{bB}}$ & $35.91^{\mathrm{bA}}$ & $36.20^{\mathrm{bA}}$ & $35.99^{\mathrm{dA}}$ & $36.61^{\mathrm{bB}}$ & $85.99^{\mathrm{bA}}$ & $98.61^{\mathrm{bB}}$ \\
\hline 5 & $51.80^{\mathrm{bA}}$ & $53.62^{\mathrm{cB}}$ & $5.67^{\mathrm{cA}}$ & $-1.25^{\mathrm{cB}}$ & $34.19^{\mathrm{cA}}$ & $35.08^{\mathrm{cA}}$ & $34.66^{\mathrm{dA}}$ & $32.04^{\mathrm{dB}}$ & $80.58^{\mathrm{cA}}$ & $92.04^{\mathrm{cB}}$ \\
\hline 13 & $51.51^{\mathrm{bA}}$ & $53.71^{\mathrm{cB}}$ & $16.02^{\mathrm{dA}}$ & $-1.54^{\mathrm{cB}}$ & $31.96^{\mathrm{dA}}$ & $34.24^{\mathrm{dB}}$ & $35.75^{\mathrm{dA}}$ & $34.27^{\mathrm{cB}}$ & $63.38^{\mathrm{dA}}$ & $92.58^{\mathrm{cB}}$ \\
\hline 15 & $44.51^{\mathrm{cA}}$ & $53.55^{\mathrm{cB}}$ & $23.65^{\mathrm{eA}}$ & $0.70^{\mathrm{dB}}$ & $31.48^{\mathrm{dA}}$ & $29.26^{\mathrm{eB}}$ & $39.37^{\mathrm{aA}}$ & $29.27^{\mathrm{eB}}$ & $53.08^{\mathrm{eA}}$ & $88.63^{\mathrm{dB}}$ \\
\hline 18 & $43.77^{\mathrm{cA}}$ & $52.38^{\mathrm{cB}}$ & $26.82^{\mathrm{fA}}$ & $18.28^{\mathrm{eB}}$ & $28.57^{\mathrm{eA}}$ & $28.95^{\mathrm{eA}}$ & $39.19^{\mathrm{aA}}$ & $34.24^{\mathrm{cB}}$ & $46.81^{\mathrm{fA}}$ & $57.73^{\mathrm{eB}}$ \\
\hline 20 & $42.21^{\mathrm{cA}}$ & $47.09^{\mathrm{dB}}$ & $27.39^{\mathrm{gA}}$ & $27.93^{\mathrm{fA}}$ & $26.82^{\mathrm{fA}}$ & $25.27^{\mathrm{fA}}$ & $38.33^{\mathrm{bA}}$ & $37.67^{\mathrm{bB}}$ & $44.40^{\mathrm{gA}}$ & $42.14^{\mathrm{fB}}$ \\
\hline
\end{tabular}




\section{Firmness}

Firmness is one of the attributes that determines its acceptance in the market. Firmness of fruits $(\mathrm{kg} / \mathrm{mm})$ decreased drastically during storage time (Figure 2). However, the film slowed down this process with respect to the controls ( $\mathrm{p}<$ 0.05 ). Tomatoes with films were firmer and more resistant to penetration. Similar results were found by Marangoni et al. (1995) where whole tomatoes an pericarp tissue progressively decreased firmness with ripening process when testing with puncture tests. Softening of tissue during ripening is a consequence of progressive changes in cell wall composition as well as cell separation (Barka et al., 2000). Firmness values derived from puncture tests reflect the integrity of pericarp tissue, where fruit-softening enzymes are primarily localized (Jackman et al., 1990). The softening of tissues during ripening results in part from progressive changes in cell wall composition as well as cell wall separation. A direct correlation was found between the rapid increase in cell wall depolymerizing enzymes and the climacteric rise in respiration and ethylene production.

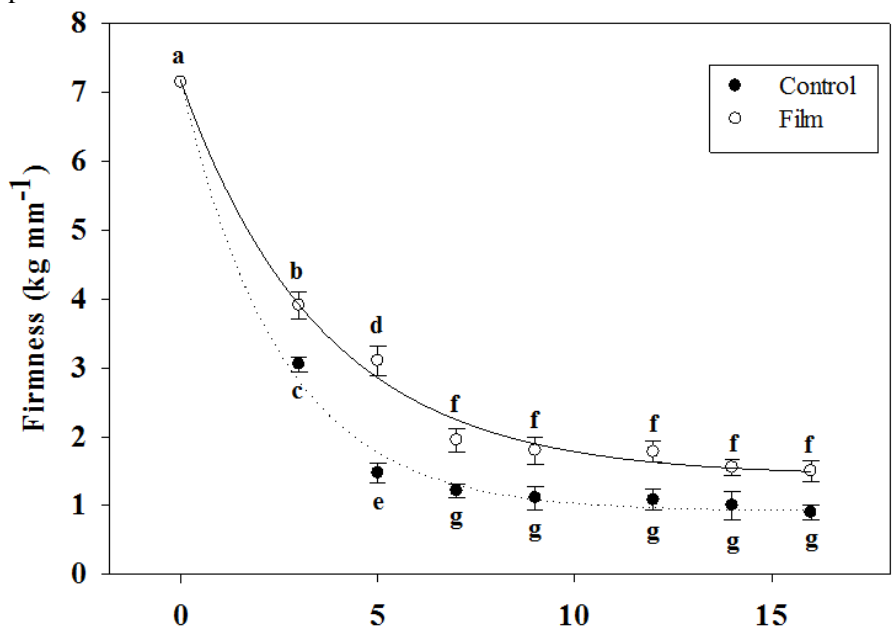

Time (d)

Figure 2 Firmness of tomatoes covered with film and control. Different letters show significant difference $(P<0.05)$.

\section{Pectin-methyl esterase activity (PME)}

Ripening is accompanied by a significative degradation of cell wall components of fruits. This degradation is promoted by the action of several hydrolytic enzymes like polygalacturonase and pectin methylesterase. Softening of stored tomato fruit flesh has been associated with the breakdown of middle lamella pectin (Barka et al., 2000). Pectinmethylesterase catalyses the demethylation of pectin. On the other hand, partially deesterified pectin can be easily depolymerized by polygalacturonase, an enzyme that has been found in large quantities in tomatoes (Van den Broeck et al., 2000). Figure 3 shows the effect of modified atmosphere created by the film on PME activity of tomatoes stored for 14 days. The same trend was observed in the control and the tomatoes coverd with the film, the activity increases since day 0 until day 7 and then decrease in they 14 . However, PME activity was always less for covered tomatoes. Statistical analysis shows differences between treatments $(\mathrm{p}<0.05)$.

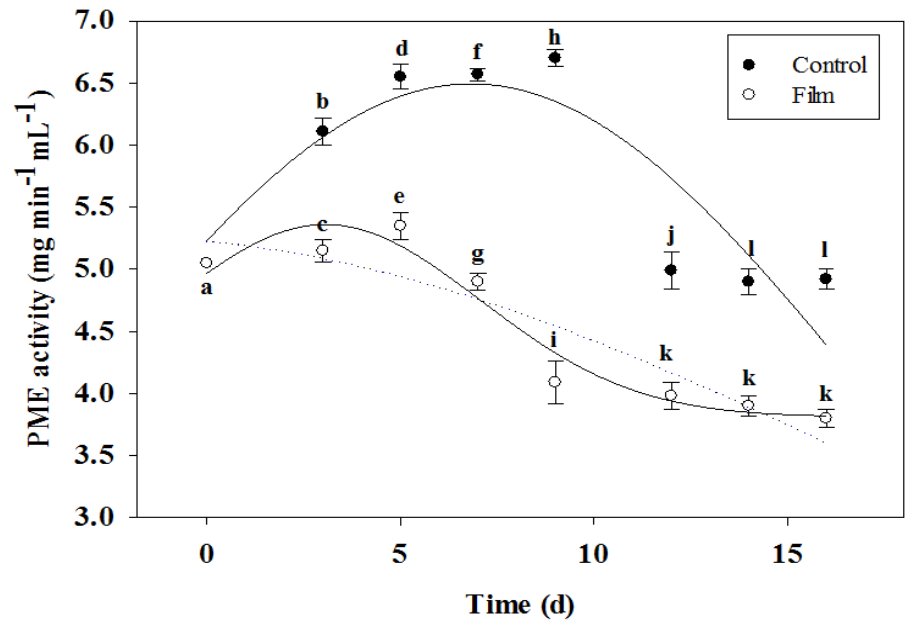

Figure 3 Effect of film over the PME activity in tomato stored for 14 days Different letters show significant difference $(P<0.05)$.
Polygalacturonase activity (PG)

PG enzyme is one of the most important enzymes associated to the cell wall degradation, catalyses hydrolytic rupture of glycoside bonds $\alpha$-D-(1-4) of non esterified D-galactopiranosiduronic residues. PG enzyme has been found in large quantities in tomatoes (Van den Broeck et al., 2000). Figure 4 shows PG activity of tomatoes stored in modified atmosphere provided by the film and contro tomatoes. In general terms there was no significant difference between treatments ( $\mathrm{p}>0.05$ ) due standar error ranged between $25 \%$ around the mean value for control and film-treated tomatoes. These results may be due to that film showed transparency and thus not prevent the passage of light, therefore it did not inhibit PG activity. Tavarini et al. (2009) observed that the light affected PG activity in Hayward kiwifruit.

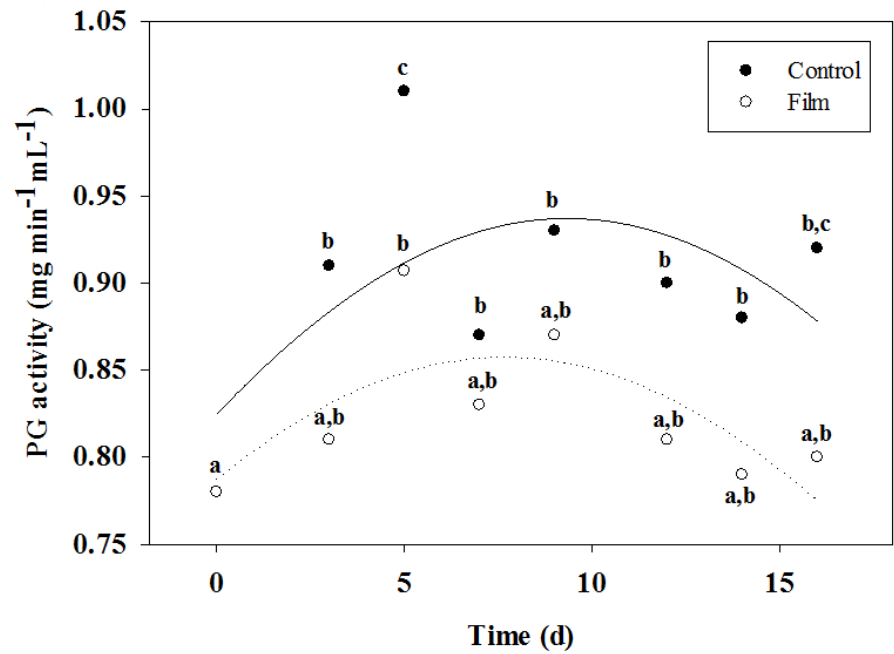

Figure 4 Effect of film over the PG activity in tomato stored for 16 days Different letters show significant difference $(P<0.05)$.

\section{Respiration rate}

The developed films created a modified atmosphere that surrounds the tomato, decreasing oxygen and increasing carbon dioxide content. This modified atmosphere decreased the ripening process when harvested in an immature stage. As a climacteric fruit, tomato has a peak where it reaches the maximum respiration rate. Control had the greatest respiration rate $(175 \mathrm{~mL} \mathrm{CO} / \mathrm{kg} \mathrm{h})$ followed by the tomatoes covered with the film $\left(140 \mathrm{~mL} \mathrm{CO}_{2} / \mathrm{kg} \mathrm{h}\right)$. Respiration in plant cells can be regulated at various points in the respiratory pathway by substrate concentration, enzymatic control and by restricting the flow rate of electrons through the electron transport chain.

\section{CONCLUSION}

Biodegradable film decreased the softening of the fruits. However, enzymatic activity and respiration rate were not affected by the film application. The results showed that the changes in tomato are due to physical effects of water loss more than a metabolic change. By using this material, it was possible to lower tomato's respiration rate in comparison with controls causing a lesser loss of weight. Biodegradable film delayed change in color as well as texture compared with controls. There was a significant difference in pectin methyl esterase activity in the covered tomato, but there was no difference in polygalacturonase activity.

Acknowledgments: We thank Arturo Ramos Martínez and Emilio Ochoa Reyes for their technical assistance.

\section{REFERENCES}

ARTÉS, F., ESCRICHE, A. J. 1994. Intermittent warming reduces chilling injury and decay of tomato fruit. Journal of Food Science, 59, 1053-1056. http://dx.doi.org/10.1111/j.1365-2621.1994.tb08188.x

ARTÉS, F., SÁNCHEZ, E., TIJSKENS, L. M. M. 1998. Quality and shelf life of tomatoes improved by intermittent warming. LWT - Food Science and Technology, 31, 427-431. http://dx.doi.org/10.1006/fstl.1997.0321

BARKA, E. A., KALANTARI, S., MAKHLOUF, J., ARUL, J. 2000. Impact of UV-C irradiation on the cell wall-degrading enzymes during ripening of tomato (Lycopersicon esculentum L.) fruit. Journal of Agricultural and Food Chemistry, 48, 667-671. http://dx.doi.org/10.1021/jf9906174

BALDWIN, E. 2005. Edible coatings. In: Environmentally friendly technologies for agricultural produce quality. Ben-Yehoshua, S. (ed.). Taylor and Francis Group LLC, 301 p. ISBN 978-0-8493-1911-2.

CAMERON, A. C., BOYLAN-PETT, W., LEE, J. 1989. Design of modified atmosphere packaging systems: modeling oxygen concentrations within sealed 
packages of tomato fruits. Journal of Food Science, 54, 1413-1416. http://dx.doi.org/10.1111/j.1365-2621.1989.tb05123.x

CASTRILLO, M., BERMUDEZ, A. 1992. Post-harvest ripening in wax-coated bocado mango. International Journal of Food Science \& Technology, 27, 457463. http://dx.doi.org/10.1111/i.1365-2621.1992.tb01211.x

DAS, D. K., DUTTA, H, MAHANTA, C. L. 2013. Development of a rice starchbased coating with antioxidant and microbe-barrier properties and study of its effect on tomatoes stored at room temperature. LWT-Food Science and Technology, 50, 272-278.

DIAZ-SOBAC, R., LUNA, A. V., BERISTAIN, C. I., CRUZ, J. D. L., GARCIA, H. S. 1996. Emulsion coating to extend postharvest life of mango (Mangifera indica cv. Manila). Journal of Food Processing and Preservation, 20, 191-202. http://dx.doi.org/10.1111/j.1745-4549.1996.tb00742.x

EL GHAOUTH, A., ARUL, J., PONNAMPALAM, R., BOULET, M. 1991. Chitosan coating effect on storability and quality of fresh strawberries. Journal of Food Science, 56, 1618-1620. http://dx.doi.org/10.1111/j.13652621.1991.tb08655.x

ERBIL, H. Y., MUFTUGIL, N. 1986. Lengthening the postharvest life of peaches by coating with hydrophobic emulsions. Journal of Food Processing and Preservation, 10, 269-279. http://dx.doi.org/10.1111/j.1745-4549.1986.tb00025.x EXAMA, A., ARUL, J., LENCKI, R. W., LEE, L. Z., TOUPIN, C. 1993. Suitability of plastic films for modified atmosphere packaging of fruits and vegetables. Journal of Food Science, 58, 1365-1370. http://dx.doi.org/10.1111/j.1365-2621.1993.tb06184.x

FOX, E., SHOTTON, K., ULRICH, C. 1995. Sigma-Stat User's Manual. Jandel Scientific Co. Inc., (cd).San Rafael, California, USA.

HAGERMAN, A. E., AUSTIN, P. J. 1986. Continuous spectrophotometric assay for plant pectin methyl esterase. Journal of Agricultural and Food Chemistry, 34, 440-444. http://dx.doi.org/10.1021/jf00069a015

JACKMAN, R., MARANGONI, A., STANLEY, D. 1990. Measurement of tomato fruit firmness. HortScience, 25, 781-783.

KADER, A. A. 1986. Biochemical and physiological basis for effects of controlled and modified atmospheres on fruits and vegetables. Food Technology, 40, 99-104.

KAMPER, S. L., FENNEMA, O. 1985. Use of an edible film to maintain wate vapor gradients in foods. Journal of Food Science, 50, 382-384. http://dx.doi.org/10.1111/j.1365-2621.1985.tb13408.x

MARANGONI, A. G., JACKMAN, R. L., STANLEY, D. W. 1995. Chillingassociated softening of tomato fruit is related to increased pectinmethylesterase activity. Journal of Food Science, 60, 1277-1281. http://dx.doi.org/10.1111/j.1365-2621.1995.tb04572.x

MCGUIRE, R. G. 1992. Reporting of objective color measurements. HortScience, 27, 1254-1255.

MCGUIRE, R. G., HALLMAN, G. J. 1995. Coating guavas with cellulose-or carnauba-based emulsions interferes with postharvest ripening. HortScience, 30, 294-295.

MCHUGH, T. H., KROCHTA, J. M. 1994. Sorbitol- vs glycerol-plasticized whey protein edible films: integrated oxygen permeability and tensile property evaluation. Journal of Agricultural and Food Chemistry, 42, 841-845. http://dx.doi.org/10.1021/jf00040a001

PHILLIPS, C. A. 1996. Review: modified atmosphere packaging and its effects on the microbiological quality and safety of produce.

PARK, H. J., CHINANN, M. S., SHEWFELT, R. L. 1994. Edible coating effects on storage life and quality of tomatoes. Journal of Food Science, 59, 568-570 http://dx.doi.org/10.1111/j.1365-2621.1994.tb05563.x

International Journal of Food Science \& Technology, 31, 463-479. http://dx.doi.org/10.1046/j.1365-2621.1996.00369.x

PRATT, H. K., MENDOZA JR, D. B. 1979. Colorimetric determination of carbon dioxide for respiration studies. HortScience, 14, 175-176.

SHEWFELT, R. L., THAI, C. N., DAVIS, J. W. 1988. Prediction of changes in color of tomatoes during ripening at different constant temperatures. Journal of Food Science, 53, 1433-1437. http://dx.doi.org/10.1111/j.13652621.1988.tb09293.x

TAVARINI, S., DEGLIINNOCENTI, E., REMORINI, D., MASSAI, R., GUIDI, L. 2009. Polygalacturonase and $\beta$-galactosidase activities in Hayward kiwifruits as affected by light exposure, maturity stage and storage time. Scientia Horticulturae, 120, 342-347. http://dx.doir.org/10.1016/j.scientia.2008.11.013

VAN DEN BROECK, I., LUDIKHUYZE, L. R., VAN LOEY, A. M., HENDRICKX, M. E. 2000. Effect of temperature and/or pressure on tomato pectinesterase activity. Journal of Agricultural and Food Chemistry, 48, 551-558. http://dx.doi.org/10.1021/jf990569n

WALPOLE, R. E., MYERS, R. H., MYERS, S. L. 1999. Probabilidad y estadística para ingenieros. Prentice-Hall Hispanoamericana, México. pp. 485551. ISBN: 9684229925.

ZAGORY, D. 1995. Principles and practice of modified atmosphere packaging of horticultural commodities. In: FARBER, J. M. and DODDS, K. (eds.) Principles of modified and sous vide product packaging. Technomic Publishing Co. Inc., Lancaster, Pennsylvania, USA., pp. 175-206. ISB N: 1566762766.

ZAGORY, D., KADER, A. A. 1988. Modified atmosphere packaging of fresh produce. Food Technology, 42, 70-77. 